\title{
sciforum
}

\section{Modulating effect of $(+)-\alpha$ - pinene on the activity of antimicrobials that interfere on protein synthesis and bacterial genetic material}

Ticiane Costa Farias ${ }^{a}$, Felipe Lemos Esteves do Amaral ${ }^{a}$, Savio Benvindo Ferreira ${ }^{b}$

${ }^{a}$ Graduate Student, Center for Teacher Training (CFP), Federal University of Campina Grande (UFCG), Cajazeiras campus, Paraíba, Brazil

${ }^{b}$ PhD Professor of the Academic Unit of Life Sciences, Center for Teacher Training (CFP), Federal University of Campina Grande (UFCG), Cajazeiras campus, Paraíba, Brazil.

\begin{tabular}{|l|l|}
\hline Graphical Abstract & $\begin{array}{l}\text { Abstract. } \\
\text { The discovery of new molecules with } \\
\text { antimicrobial activity, and the understanding of } \\
\text { the mechanisms of action, are important } \\
\text { strategies against multiresistant pathogens. The } \\
\text { positive enantiomer of } \alpha \text {-pinene appears as an } \\
\text { alternative to combat them, since it inhibits the } \\
\text { growth of microorganisms, including strains of } S . \\
\text { aureus, which gives the possibility of its use as an } \\
\text { antimicrobial agent, isolated or in combination } \\
\text { with other drugs. Therefore, the main goal of this } \\
\text { study is to evaluate the modulating effect of }(+)- \\
\alpha-p i n e n e \text { on the activity of synthetic } \\
\text { antimicrobials that act on protein synthase and } \\
\text { interfere with bacterial genetic material. The }\end{array}$ \\
\hline RIfanpicin
\end{tabular}




\begin{tabular}{|l|l|}
\hline $\begin{array}{l}\text { modulating effect of }(+)-\alpha \text {-pinene on the activity } \\
\text { of antibiotics for clinical use on some } S \text {. aureus } \\
\text { strains was studied using the modified disc- } \\
\text { diffusion method. The disks contain the following } \\
\text { antimicrobials: Ciprofloxacin } 5 \mu \text {, Tetracycline } \\
30 \mu g, \text { Nitrofurantoin } 300 \mu \text { and Rifampicin } 5 \\
\mu g .50 \text { microliters of }(+)-\text { alpha-pinene (160 } \\
\mu \mathrm{L} / \mathrm{mL}) \text { were added to the disks containing the } \\
\text { antimicrobials to verify the modulating effect of } \\
\text { monotrepene. Indifferent activity was observed in } \\
\text { the association between the phytoconstituent and } \\
\text { the four tested antimicrobials. Further studies } \\
\text { using new methods in order to evaluate the } \\
\text { antimicrobial activity of the association between } \\
\text { the (+) } \alpha-\text { pinene and commercial antimicrobials } \\
\text { are still needed. }\end{array}$ \\
\hline
\end{tabular}

\section{Introduction}

Bacterial resistance is a major challenge in global health, affecting both developed and emerging countries, as there is a significant increase in the number of bacterial strains increasingly resistant to antibiotic therapy available today. Thus, the control of infections in the hospital environment is difficult, resulting in prolonged hospitalization, the need to use more expensive medicines and health services, as well as increased mortality of patients, especially the most vulnerable., such as the elderly, children, immunosuppressed, patients admitted to the intensive care unit (ICU) (SANTOS, 2004; REIS et al., 2013).

Analyzing the data from the 1940s to the mid-1960s, we can find several discoveries of antimicrobials developed from experiments with natural products. These agents have been shown to be efficient in the treatment of gram-positive bacteria, and these substances are present in the antimicrobial classes: $\beta$-lactams, aminoglycosides, tetracyclines, macrolides, peptides, among others. (GOODMAN, 2006; GUIMARÃES et al., 2010).

Given this perspective, the positive enantiomer of $\alpha$-pinene appears as an alternative to combat them, as it has been observed in the literature that it was able to inhibit the growth of microorganisms, including strains of Staphylococcus aureus, which gives it the possibility of use as an antimicrobial agent alone or in combination with other drugs (SILVA et al., 2012; EDUARDO et al., 2017). Therefore, this 
research aims to evaluate the modulating effect of $(+)-\alpha$-pinene on the activity of synthetic antimicrobials acting on protein synthase and interfering with bacterial genetic material.

\section{Materials and Methods}

Phytoconstituent (+) - $\alpha$ - pinene (+ AP) was obtained from the company Sigma-Aldrich do Brasil Ltda and the solutions were prepared at the time of testing, first dissolving them in $1 \%$ Tween 80 and 5\% DMSO, and using sterile distilled water to achieve desired concentrations (CLEELAND; SQUIRES, 1991). In the performance of the tests to evaluate the phytoconstituent antibacterial activity, the culture medium used was Mueller-Hinton Agar (AMH), (HIMEDIA, India), which was prepared according to the manufacturer's guidelines.

To perform the modulation test, discs containing the commercial antimicrobial (ATM) were used: CIP - Ciprofloxacin 5 $\mu \mathrm{g}$, TET - Tetracycline $30 \mu \mathrm{g}$, NIT - Nitrofurantoin $300 \mu \mathrm{g}$ and RIF Rifampicin $5 \mu \mathrm{g}$. The modulating action of monoterpene on the antimicrobial activity of antibiotics for clinical use on standard S. aureus strains ATCC 25923 was determined by the modified disc diffusion method (BAUER et al., 1966), modified (OLIVEIRA et al., 2006). Commercial discs of antimicrobial agents (ATB) were applied to the medium surface and to each disc were added $20 \mu \mathrm{L}(+)$ - $\alpha$-pinene (+ AP) with a concentration of $160 \mu \mathrm{L} / \mathrm{mL}$ (EDUARDO et al., 2017). To evaluate the effect of the + AP - ATM combination, ATM disks without the addition of + AP were tested.

After incubation of the plates at $35^{\circ} \pm 2{ }^{\circ} \mathrm{C}$ for 24 hours, the diameters of the microbial growth inhibition halos were read. The halos diameters formed by each AP + ATM association were compared to those determined by the ATM alone. A synergistic effect was considered when the combination showed an increase in inhibition halo diameter $\geq 2 \mathrm{~mm}$; antagonistic effect when the diameter of the halos determined by the combination was smaller than that of the isolated ATM; and indifferent effect, when the combination demonstrated an increase in the ATM halo diameter <2mm (CLEELAND; SQUIRES, 1991).

All experiments were performed in triplicate. Results were statistically treated using GraphPad Prism 5.0 software (GraphPad Software, Inc., San Diego, CA). Data were submitted to analysis of variance (ANOVA) and expressed as mean + standard deviation. Differences were assessed by paired t-test. Differences were considered significant when $p \leq 0,05$.

\section{Results and Discussion}


http://sciforum.net/conference/mol2net-05

As it is oily in nature, preparation of the phytoconstituent dilution was carried out with the aid of surfactants which, according to the literature, these solvents DMSO and Tween 80 do not have antimicrobial activity at the concentrations used, 5\% and 1\%, respectively (BRITO et al., 2017; SILVA, et al., 2017).

After the experiments, it is possible to observe the differences in the average diameter of the inhibition halos $(\mathrm{IH})$ before and after the association with the phytoconstituent. The S. aureus ATCC 25923 strain was found to be sensitive to all antibiotics before and after association with (+) - $\alpha$-pinene, ie the association with antimicrobials with phytoconstituent did not lead to a qualitative change. sensitivity profile of the microorganism.

As shown in Figure 1, which shows a comparison between the means of the size of the isolated inhibition halos and in association with the monoterpene, the following diameter values were found for the isolated antimicrobials: $(+)-\alpha$-pinene: $14,33 \mathrm{~mm}( \pm 1.53 \mathrm{~mm})$, ciprofloxacin: $27.00 \mathrm{~mm}( \pm 1.73$ $\mathrm{mm})$, rifampicin: $34.33 \mathrm{~mm}( \pm 3.06 \mathrm{~mm})$, tetracycline: $31.67 \mathrm{~mm}( \pm 2.08 \mathrm{~mm})$ and nitrofurantoin: 23.00 $\mathrm{mm}( \pm 1.00 \mathrm{~mm})$.

Figure 1 - Comparation of the sizes of the diameters of halos of inhibition of bacterial growth alone and in combination commercial antimicrobial against S. aureus ATCC 25923.

\section{Staphylococcus aureus ATCC 25923}

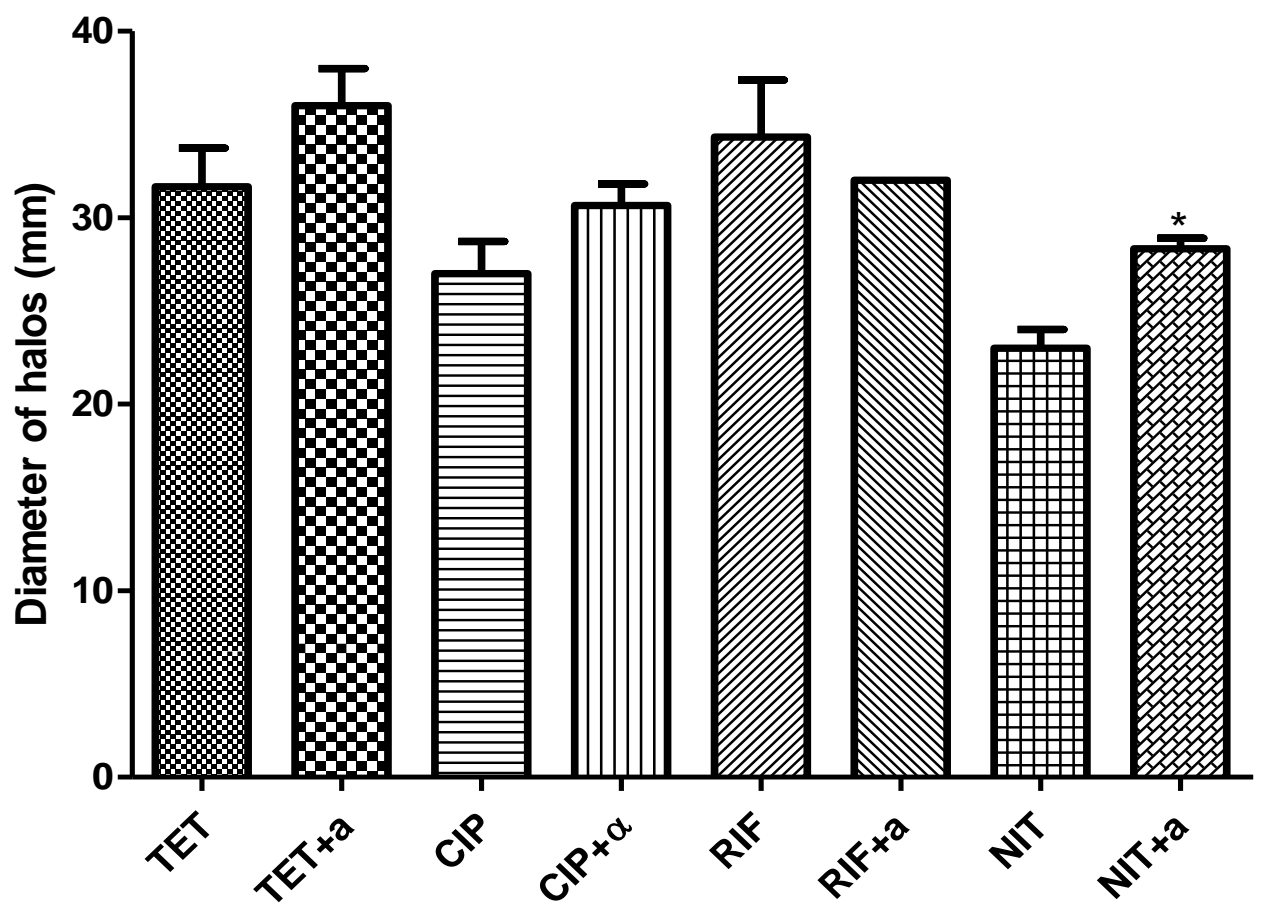

Antibiotics Isolated and Associated with (+)- $\alpha-$ pinene

Then, the association test of antimicrobial activity with phytoconstituent was performed. After the combination, the values of the growth inhibition halo diameters were changed to: ciprofloxacin: 
$30.67 \mathrm{~mm}( \pm 1.56 \mathrm{~mm})$, rifampicin: $32 \mathrm{~mm}( \pm 0.00 \mathrm{~mm})$, tetracycline: $36.00 \mathrm{~mm}( \pm 2.00 \mathrm{~mm})$ and nitrofurantoin: $28.33 \mathrm{~mm}( \pm 0.58 \mathrm{~mm})$. After conducting the association experiment between the $+\mathrm{AP}$ and the ATMs used, it can be observed that no ATM used showed a statistically significant difference, so as to consider the indifferent effect.

\section{Conclusions}

Given the results obtained, with the indifferent effect found for the four antimicrobials under study, further research using new methodologies is recommended to evaluate the antimicrobial activity of the association between monoterpene and other commercial antimicrobials.

\section{References}

[1] Bauer, et al. Antibiotic susceptibility testing by a standardized single disk method. Am J Clin Pathol. 1966 Apr;45(4):493-6

[2] Brito et al. Standardization of the Safety Level of the Use of DMSO in Viability Assays in Bacterial Cells. MOL2NET 2017, International Conference on Multidisciplinary Sciences, 3rd edition.

[3] Cleeland, R., Squires, E. Evaluation of new antimicrobials in vitro and experimental animal infection In: Lorian, V. Antibiotics in laboratory medicine. 3. ed. Baltimore: Williams and Wilkiam, pp. 739-787. 1991.

[4] Clinical Laboratory Standards Institute (CLSI). Metodologia dos Testes de Sensibilidade a Agentes Antimicrobianos por Diluição para Bactéria de Crescimento Aeróbico: Norma Aprovada - Sexta Edição. M7-A6 Vol. 23 No. 2 Substitui a Norma M7-A5 Vol. 20 No. 2 .

[5] Eduardo, LS. Farias, TC. Ferreira, SB. Lima, ZN. Análise da atividade antibacteriana do enântiomero positivo do alfa-pineno frente às cepas de Staphylococcus aureus e Enterococcus faecalis. In: II CONBRACIS, 2017, Campina-Grande. II CONBRACIS. Campina Grande-PB: Realize eventos, 2017. v. 1 .

[6] GOODMAN. As Bases Farmacológicas da Terapêutica. 11. ed. Rio de Janeiro: McGraw-Hill, 2006. [7] Oliveira R, Lima EO, Vieira WL, Freire KL, Trajano V, Lima IO, et al. Estudo da interferência de óleos essenciais sobre a atividade de alguns antibióticos usados na clínica. Rev Bras Farmacogn. 2006;16(1):77-82.

[8] Reis, HPLC, et al. Avaliação da resistência microbiana em hospitais privados de Fortaleza - Ceará. Rev. Bras. Farm. 94 (1): 83-87, 2013.

[9] Santos DA, Hamdan JS. Evaluation of broth microdilution antifungal susceptibility testing conditions for Trichophyton rubrum. Journal of Clinical microbiology, 43 (4), 1917-1920. 2005.

[10] Santos, NQ. A resistência bacteriana no contexto da infecção hospitalar. Red de Revistas Científicas de América Latina y el Caribe, España y Portugal. Texto Contexto Enferm 2004; 13(n.esp):64-70. 
[11] Sikkema, J. De Bont, JAM. Poolman, B. Interactions of cyclic hydrocarbons with biological membranes. The Journal of Biological Chemistry, v.269, p.8022-8, 1994.

[12] Silva, ACR, et al. (2012). Biological Activities of $\alpha$-Pinene and $\beta$-Pinene Enantiomers. Molecules, $17,6305-6316$.

[13] Silva, G. et al. Evaluation of the Interference of Solvents Used in the Evaluation of Antimicrobial Activity of Liposoluble Natural Compounds MOL2NET 2017, International Conference on Multidisciplinary Sciences, 3rd edition.

[14] Trombetta, D, et al. Mechanisms of antibacterial action of three monoterpenes. Antimicrobial Agents and Chemotherapy, v.49, n.6, p.2474-8, 2005. 